\title{
NEATSAKYTI IR DISKUTUOTINI TARPUKARIO LIETUVOS KARIUOMENĖS (1938-1940) ISTORIOGRAFIJOS KLAUSIMAI
}

\author{
Egidijus PAPEČKYS
}

\section{IVADAS}

Kiekvieną naują leidinį apie tarpukario Lietuvos kariuomenès istoriją su dideliu susidomejjimu sutinka ne tik akademinè visuomené, bet ir daugybé karo istorijos mėgèjų. Iki šiol didžiausią veikalą apie tarpukario Lietuvos kariuomenę yra pateikęs Vytenis Statkus ${ }^{1}$. Vèliau pasirodęs dr. Algimanto Liekio darbas ${ }^{2}$, nors ir labai didelès apimties, kurio II dalyje „Karyba ir ginkluote Nepriklausomoje Lietuvoje (1918-1940) “ daugiausia atkartojama prieškario Štabu žinyno ${ }^{3}$ ir V. Statkaus jau pateikta informacija, nors ir papildyta dar nepublikuotais archyviniais dokumentais, savo svarba V. Statkaus studijai neprilygsta. Plk. ltn. dr. Gintauto Surgailio knyga ${ }^{4}$, kurioje glaustai, bet išsamiai supažindinama su Lietuvos tarpukario kariuomene, jos organizacija, ginkluote, technika ir ịvairiomis kitomis kariuomenès gyvenimo sritimis bei aspektais, labai vertintina dẻl informacijos aiškumo ir paprastumo ja naudotis, yra gerokai mažesnès apimties (kitų darbų čia neminèsiu, kadangi juose paliečiami tik atskiri Lietuvos kariuomenès istorijos aspektai). Deja, visi šie leidiniai išleisti palyginti seniai. Todèl perskaitęs doc. dr. V. Lesčiaus straipsni „Lietuvos kariuomenés organizavimo, dislokavimo ir ginkluotés pokyčiai 1938-1940 m." ${ }^{\text {"5 }}$ labai nudžiugau, kad pagaliau sulaukiau naujo kompleksinio darbo, apimančio visas tarpukario Lietuvos kariuomenès ginklų rūšis, nagrinèjančio jų organizavimo, ginkluotės ir dislokavimo ypatumus. Savaime suprantama, kad tai ne kelių tomų monografija ir joje netilpo viskas, ką autorius būtų

1 V. Statkus, Lietuvos ginkluotosios pajègos 1918-1940 metais, Čikaga, 1986.

2 A. Liekis, Lietuvių karyba ir ginkluote, Vilnius, 2002.

3 Štabų žinynas, Kaunas, 1938.

4 G. Surgailis, Lietuvos kariuomenè 1918-1998, Vilnius, 1998.

5 V. Lesčius, Lietuvos kariuomenès organizavimo, dislokavimo ir ginkluotès pokyčiai 1938-1940 m. // Karo archyvas, t. XXIV, 2009, p. 116-205. 
norejjęs pateikti. Tačiau doc. dr. V. Lesčius, kuris darbe „Lietuvos kariuomené 1919-1920 m." išsamiai atskleidė Nepriklausomybės kovų istoriją, nenuvylė ir šį kartą. Šaltinių, kurių dauguma iki šiol nebuvo viešai paskelbti, gausa leidžia visiškai kitaip pažvelgti i 1938-1940 m. Lietuvos kariuomenę.

Vis dèlto skaitytojai stokoja ne tik naujų studijų tarpukario Lietuvos kariuomenès istorijos tema. Kaip karo istorijos mėgejjas Lietuvos kariuomenès istoriją tiriančių istorikų darbuose vis dar pasigendu naujos informacijos, kuri leistų pašalinti metų metais neužpildomas „baltas dėmes“. I labai daug tokių klausimų radau atsakymus minètame doc. dr. V. Lesčiaus straipsnyje. Vis dèlto dar lieka ir neatsakytų, todèl noriu pateikti keletą savo minčių ne tik apie tai, ko šiame straipsnyje neradau arba kas man pasirode diskutuotina, bet ir apie kai kuriuos tarpukario Lietuvos kariuomenés istoriografijoje nevisiškai atskleistus ar apskritai neatskleistus klausimus. Galbūt dauguma jų puikiai žinomi akademinei visuomenei, tiktai, deja, nebuvo paskelbti (išspausdinti). Todėl norètųsi profesionaliems istorikams priminti, kad jų darbų laukia ir didelis karo istorijos mégèjų būrys.

Dar viena įsisenejjusi darbų apie tarpukario Lietuvos kariuomenę problema - autoriaus vertinimai. Šaltinis po šaltinio, faktas po fakto kaip mozaika lipdoma kariuomenès istorija. Ar to užtenka? Juk kariuomenė neegzistavo viena pati sau, ji nebuvo vien Lietuvos Respublikos dalis. Kariuomenė turejjo užduotis, paskirtị, i tai atsižvelgiant ir buvo organizuojama, mokoma ir ginkluojama. Visiškai čia pat, greta, savo pajègas organizavo, mokèsi ir ginklavosi mūsų artimesni ir tolimesni kaimynai, draugai ir priešai, Latvijos, Estijos, Lenkijos, Vokietijos, Sovietų Sajungos ir kitų šalių kariuomenès. Kai kurios iš jų planavo ir rengè karo veiksmus prieš Lietuvos Respubliką, prieš Lietuvos kariuomenę. Lietuvos kariuomenè analogiškai planavo karo veiksmus prieš galimus agresorius. Argi galima vertinti kokią nors kariuomenę, nepalyginus jos su kitų šalių, potencialių priešininkių, kariuomenėmis? Be to, Žiemos karas ir ypač Antrasis pasaulinis karas patikrino juose dalyvavusių šalių kariuomenių pasirengimą karo veiksmams, patvirtino ar sugriove ịvairias prieškario doktrinas. Realių ir nuožmių karo veiksmų metu keitėsi kariuomenių organizacija ir ginkluote. Ar Lietuvos kariuomenès vadovybè numate šiuos pokyčius, ar tinkamai rengè kariuomenę? Štai ị tokius klausimus, mano nuomone, turètų atsakyti istorikas, atliekantis kariuomenès istorijos tyrimus ir pateikiantis savo vertinimus. Minètame doc. dr. V. Lesčiaus straipsnyje tokių vertinimų nemažai. Savaime suprantama, kad bet kokie vertinimai gali būti kritikuojami ir diskutuojami, tačiau jie reikalingi ir laukiami.

Pirmiausia norèčiau atkreipti dèmesị ị tam tikras Lietuvos kariuomenès istoriografijoje naudojamų šaltinių ypatybes. Ilgus metus mūsų išeivija buvo 
atkirsta nuo Lietuvoje esančių archyvų, todèl jos pokario šaltiniai grịsti beveik išimtinai istorinių ịvykių dalyvių ir amžininkų atsiminimais. Nors tokie atsiminimai ir laikomi pirminiais šaltiniais, tai yra labai subjektyvi istoriné medžiaga, kuri bėgant laikui gali būti tyčia ar netyčia iškraipoma, t. y. nebeatitikti tikrovès. Tą pažymi ir V. Statkus, savo darbe kritiškai vertindamas vienus ar kitus atsiminimus ${ }^{6}$. Dar didesnè problema - šaltinių, kuriuose pateikiami ịvairūs duomenys, pvz., ginkluotès kiekis skaičiais, jos tipai ir pan., ypač kai tai nežinia kieno atsiminimais paremta informacija, patikimumas. Vèliau pabandysiu įrodyti, kad naudojant tokius duomenis (kai nèra dokumentiniu šaltinių) galima visiškai iškreipti faktines aplinkybes. Todẻl, mano nuomone, analizuojant istorijos šaltinius, jeigu tai įmanoma, atsiminimai ir archyviniai dokumentai turètų būti vertinami ne atskirai, o kaip papildantys vienas kitą.

Lietuvos archyvuose esantys originalūs Lietuvos kariuomenès dokumentai, atsiradę po $1939 \mathrm{~m}$. Vokietijos-Lenkijos karo veiksmų, taip pat turi didelių „minusų“. Šis karas šokiravo viso pasaulio kariškius. Iš karto po jo trūko objektyvios informacijos, labai aktyviai veikè Vokietijos propagandos mašina, todèl buvo padaryta daug skubotų išvadų, kurios vẻliau, Antrojo pasaulinio karo (toliau - APK) metu, nepasitvirtino. Todèl nederètų spręsti apie Lietuvos kariuomenę remiantis tik šiais šaltiniais ir neatsižvelgiant APK patirtị. Kita svarbi aplinkybè - negalima tinkamai ịvertinti Lietuvos kariuomenės, nepalyginus jos su kitų šalių, ypač potencialių to meto priešininkių, kariuomenėmis. Ypač tai pasakytina apie šiuolaikines ginklų rūšis ir ginkluotę. Tarpukariu, iki 1938 m. kovo ar net iki Lenkijos Respublikos sutriuškinimo 1939 m., didžiausią grèsmę Lietuvos valstybingumui, kad ir kaip būtų gaila, kèlè Lenkija, todèl pagrindinis Lietuvos kariuomenès priešas buvo Lenkijos kariuomenè. Palyginti su Lenkijos kariuomenès organizacija ir ginkluote, Lietuvos kariuomenès prieštankinès, priešlèktuvinès ir karo aviacijos galimybės, pvz., 1938 m. kovą, buvo visiškai kitokios, negu jai kovojant su Vokietijos ir Sovietų Sajungos karinėmis pajėgomis 1939 ir 1940 metais. Vadinasi, būtų klaidinga Lietuvos kariuomenę ir jos ginklų rūšis 1938-1940 m. laikotarpiu visą laiką vertinti vienodai. Šiuos savo teiginius pabandysiu pagrịsti kituose straipsnio skyriuose.

Norèčiau paminèti dar vieną svarbią šaltinių grupę, kažkodèl beveik neminimą ir nenaudojamą Lietuvos kariuomenès istoriografijoje, - kariuomenès

6 V. Statkus, Lietuvos ginkluotosios pajëgos 1918-1940 metais, Čikaga, 1986. 
statutus: Pèstininkų ${ }^{7}$, Artilerijos ${ }^{8}$, Kavalerijos $^{9}$, Žvalgomosios aviacijos ${ }^{10}$ ir kt. Šio straipsnio tikslas ne peržvelgti ar recenzuoti visą Lietuvos kariuomenès istoriografiją, o pabandyti karo istorijos mėgèjo akimis pažvelgti ị jos neatsakytus klausimus, diskutuotinas aplinkybes, šaltinius ir Lietuvos kariuomenès veiksmų lemtingais 1938-1940 m. vertinimus, kai kuriais klausimais pateikti savo nuomonę. Tikiuosi, kad šis mano straipsnis, kurio teiginių nelaikau vieninteliais teisingais ir neginčytinais, pagyvins diskusiją ir galbūt padès pašalinti kai kurias „baltas dėmes“. Kadangi iš mano minètų darbų doc. dr. V. Lesčiaus straipsnis pasirodè vèliausiai, yra kompleksinis ir didelès apimties, diskutuotinus ir neatsakytus klausimus, susijusius su kariuomenès organizavimu ir ginkluote, pateiksiu šio autoriaus nagrinėtų ginklų rūšių tvarka.

\section{PÉSTININKAI}

Savo straipsnyje doc. dr. V. Lesčius pateikia daug naujų dokumentų, susijusių su pèstininkų pajègų organizavimo, ginkluotès ir dislokavimo ypatumais ${ }^{11}$. Pvz., labai sudomino lentelès, kuriose nurodyti péstininkų pulko taikos meto etatai, tačiau pasigedau duomenų, kokia turejjo būti pėstininkų pulko, divizijos organizacija karo metu, nes tai labai svarbus rodiklis. Iki šiol tokie duomenys pateikti minètuose A. Liekio ir V. Statkaus darbuose, tačiau abiejų paimti tik iš 1938 metų Štabų žinyno ${ }^{12}$. Tiesa, V. Statkus šiuos duomenis papildè atsiminimais, bet archyvinių dokumentų dèl anksčiau paminètų priežasčių jo darbe trūksta. Labiausiai diskutuotina doc. dr. V. Lesčiaus straipsnio dalis apie pagrindinę Lietuvos kariuomenès jëgą - pèstininkus pasirodè ši buvusio kariuomenès vado divizijos generolo S. Raštikio atsiminimų ištrauka:

„<...>pasak paties buvusio kariuomenès vado div. gen. S. Raštikio, pèstininku divizijos ir ju struktūra tebebuvo per sunkios ir nejudrios. Tiek jose, tiek péstininku pulkuose tebebuvo per didele péstininku masé, kuria, reikalui esant, buvo sunku greitai perkelti iš vienos vietos ị kitą. Šị uždavinị operatyviai spręsti dar kliudè ir tai, jog krašte labai stokojo susisiekimo priemoniu žmonèms ir kroviniams vežti. Lietuvos sąlygomis reikëjo siekti žmoniu skaičiumi mažesnès, bet

\footnotetext{
7 Pèstininkų statutas. D. I. Rikiuotè, Kaunas, 1936; D. II. Kautynès, Kaunas, 1936 ir 1939.

8 Artilerijos statutas, Kaunas, 1938.

9 Kavalerijos statutas, Kaunas, 1938.

10 Žvalgomosios aviacijos statutas, Kaunas, 1939.

11 V. Lesčius, Lietuvos kariuomenès organizavimo, dislokavimo ir ginkluotès pokyčiai 1938-1940 m. // Karo archyvas, t. XXIV, 2009, p. 127-141.

12 Štabų žinynas, Kaunas, 1938.
} 
lengvai vadovaujamos, judrios, lanksčios ir paslankios motomechanizuotos ir šarvuotos kariuomenès, susidedančios iš atskiru sustiprintu batalionu, kuriuos tik vadovavimo atžvilgiu, reikalui esant, būtu galima sujungti į atskirus pulkus, o nuo sunkių ir nepaslankių bei nejudriu péstininku diviziju - net visai atsisakyti. "

Ypač diskutuotinas autoriaus teiginys: „Kaip matysime, kariuomenès vadovybè véliau siekè ta kryptimi eiti. "13

Šioje citatoje suformuluota mintis atsisakyti pėstininkų divizijų ir pereiti prie atskirų sustiprintų batalionų. Tačiau toliau darbe nèra pateikiama jokių kitų atsiminimų, dokumentų ar kitų šaltinių, patvirtinančių ši teiginị. Atvirkščiai, nuolat pabrèžiama, kad Lietuvos kariuomenè turi būti sudaryta iš 3-4 divizijų. Nors tokia mintis - išskaidyti kariuomenę ị atskirus sustiprintus batalionus - iš pirmo žvilgsnio atrodytų patraukli, bet pavienius batalionus aprūpinti ir, svarbiausia, užtikrinti ryši bei valdyti buvo neįmanoma. Be to, nebuvo jokių galimybių nei jų mechanizuoti, nei suteikti šiems batalionams pakankamai ugnies galios, nei pajėgumų, kad jie galètų atsilaikyti prieš didesnius priešo junginius. Apie tai nerasite parašyta jokiame karybos vadovėlyje nei APK patirtị apibendrinančiuose darbuose, apie tai daugiau neužsimena ir pats generolas S. Raštikis.

APK metu kitų šalių pėstininkų divizijos - pagrindinio Lietuvos kariuomenès junginio - organizacija beveik nepakito. Tiek APK pradžioje, tiek pabaigoje beveik visų šalių pėstininkų divizijas sudare tokie pat daliniai ir padaliniai, labiausiai pasikeite tik jų ginkluote. Divizijose atsirado daugiau automatinių, prieštankinių ginklų, minosvaidžių, savaeigès artilerijos ir transporto. Pvz., tiek Sovietų Sajungos, tiek Vokietijos péstininkų divizijas karo pabaigoje, kaip ir pradžioje, sudare 3 šaulių/pèstininkų, 1-2 artilerijos pulkai, prieštankinès ir priešlèktuvinès gynybos kuopos, batalionai ar divizionai, žvalgybos, ryšių, pionierių batalionai. Žinoma, dèl gausesnio aprūpinimo automatiniais ginklais ir didelių gyvosios jègos nuostolių šiek tiek sumažèjo kovos dalinių karių skaičius, o Vokietijos kariuomenès kai kuriuose pulkuose - nuo 3 iki 2 péstininkų batalionų. Karių ir ginkluotès skaičius Lietuvos ir Lenkijos pesstininkų ir Vokietijos ir Sovietų Sajungos pèstininkų/šaulių divizijose bei pastarųjų pokyčiai karo metu matyti pateiktų duomenų lentelèje.

13 V. Lesčius, Lietuvos kariuomenès organizavimo, dislokavimo ir ginkluotès pokyčiai 1938-1940 m. // Karo archyvas, t. XXIV, 2009, p. 129. 


\begin{tabular}{|c|c|c|c|c|c|c|}
\hline & $\begin{array}{l}\text { Lietu- } \\
\text { vos } \\
\mathrm{PD}^{1^{*}}\end{array}$ & $\begin{array}{l}\text { Len- } \\
\text { kijos } \\
\text { PD }^{2^{*}}\end{array}$ & $\begin{array}{c}\text { SSRS } \\
\text { Etatas } \\
\text { Nr. } \\
04 / 100^{3^{*}}\end{array}$ & $\begin{array}{c}\text { SSRS } \\
\text { Etatas } \\
\text { Nr. } 05 / 40^{4^{*}}\end{array}$ & $\begin{array}{l}\text { Vokie- } \\
\text { tijos } \\
\mathrm{PD}^{5^{*}}\end{array}$ & $\begin{array}{l}\text { Vokie- } \\
\text { tijos } \\
\text { PD }^{6^{*}}\end{array}$ \\
\hline & $\begin{array}{c}1938- \\
40\end{array}$ & 1939 & $1940-06-10$ & $1944-12-18$ & $1939-40$ & 1943 \\
\hline Kariu & 14845 & 15977 & 17166 & 11076 & 17734 & 13674 \\
\hline Lengvųjų kulk. & 301 & 326 & 437 & 337 & 435 & 672 \\
\hline Sunkiųjų kulk. & 116 & 132 & 166 & 166 & 110 & 102 \\
\hline Zenitinių kulk. & & & 33 & 18 & & \\
\hline 46 ir $50 \mathrm{~mm}$ min. & & 81 & 84 & & 84 & \\
\hline 81 ir $82 \mathrm{~mm}$ min. & 12 & 20 & 54 & 89 & 54 & 54 \\
\hline $120 \mathrm{~mm}$ min. & & & 12 & 38 & & 32 \\
\hline PT šautuvų & & 92 & 60 & 107 & 90 & 99 \\
\hline \multicolumn{7}{|l|}{ PT granatsvaidžių } \\
\hline 75 ir $76 \mathrm{~mm}$ pulko pab. & & 6 & 18 & 12 & 20 & 19 \\
\hline $150 \mathrm{~mm}$ pulko pab. & & & & & 6 & 6 \\
\hline 37 ir $45 \mathrm{~mm}$ PT pab. & & 27 & 54 & 18 & 75 & \\
\hline 50 ir $57 \mathrm{~mm}$ PT pab. & & & & 18 & & 1 \\
\hline $75 \mathrm{~mm} \mathrm{PaK} 40$ & & & & & & 49 \\
\hline $20 \mathrm{~mm}$ aut. pab. & 18 & & & & 12 & 12 \\
\hline 37 ir 40 mm PLG pab. & & 4 & 8 & 12 & & \\
\hline 76 mm PLG pab. & & & 4 & & & \\
\hline 75 ir $76 \mathrm{~mm}$ lauko patr. & 24 & 24 & 16 & 32 & & \\
\hline 100-122 mm lauko haub. & 12 & 12 & 32 & 20 & 36 & 36 \\
\hline 150 ir $155 \mathrm{~mm}$ s. haub. & & & 12 & & 12 & 12 \\
\hline SPTP „Marder“ & & & & & & 14 \\
\hline Šarvuotų automobilių & & & 13 & & 3 & \\
\hline Tankų (̌̌v.) & & & 16 & & & \\
\hline Motociklų & 28 & & & & 527 & 158 \\
\hline Automobilių & 54 & 76 & 827 & 342 & 999 & 547 \\
\hline Traktorių & & & 88 & & & \\
\hline Arklių & 5301 & 6937 & 4218 & 1200 & 4842 & 5072 \\
\hline
\end{tabular}

1* Štabų žinynas, Kaunas, 1938, p. 6-19.

2* T. Jurga, Obrona Polski 1939, Warszawa, 1990, s. 254.

$3^{*}$ http://www.rkka.ru

$4^{*}$ Ten pat.

5* M. Bryja, Piechota niemiecka 1939-1945, Warszawa, 1999, s. 15.

6* Ten pat, p. 42-43 
Reikètų pažymèti, kad dauguma Vokietijos ir Sovietų Sajungos pėstinin$\mathrm{ku} / \check{s}$ sulių divizijų buvo ginkluotos prasčiau, nei numatyta pagal etatus. O Lietuvos kariuomenei pakako ginklų pagal etatus numatytam skaičiui divizijų apginkluoti. Palyginus pateiktus duomenis, LK péstininkų divizijoje akivaizdus prieštankinių, priešlèktuvinių priemonių, minosvaidžių, artilerijos ir motorinių transporto priemonių trūkumas. Šiek tiek palyginkime Lietuvos ir Lenkijos péstininkų divizijas. Abiejų organizacija beveik analogiška: 3 pèstininkų pulkai po 3 pèstininkų/šaulių batalionus, artilerijos pulkas, ryšių batalionas, pionierių/inžinerijos ir kiti padaliniai. Tačiau lenku divizija atitinkamą lietuvių dalinị beveik dvigubai lenkè minosvaidžių skaičiumi, prieštankinèmis priemonėmis - trečdaliu. Be to, lenkų divizija turèjo priešlèktuvinès gynybos bateriją ${ }^{14}$, ginkluotą $40 \mathrm{~mm}$ PLG pabūklais „W.Z. 36 Bofors" (nors karo veiksmų metu kai kurios šių baterijų buvo iš divizijų paimtos ir skirtos tiltų ir kitų objektų priešlèktuvinei apsaugai užtikrinti). Lietuvos pèstininkų divizija neturèjo nè vieno specializuoto priešlèktuvinès gynybos dalinio, kaip ir jokių specializuotos priešlèktuvinès gynybos priemonių. Teoriškai $20 \mathrm{~mm}$ automatiniai pabūklai „Oerlikon“ galejjo šaudyti i oro ir i žemès taikinius. Tačiau jie buvo perduoti šaulių bataliono vado žinion (būrys su 2 automatiniais pabūklais). O arkliais traukiamu pabūklu užtikrinti šaulių bataliono priešlèktuvinès apsaugos žygio metu, kai aviacijos antpuolis pavojingiausias, padalinys negalèjo. Batalionui įrengtose gynybos pozicijose aviacija, ypač to meto, atsižvelgiant į APK patirtic ${ }^{15}$, toli gražu nebuvo tokia baisi kaip tankai. Pèstininkų statute buvo nustatyta šių pabūklų paskirtis: „Automatinis pabūklas skiriamas šaudyti priešo lèktuvams ir šarvuočiams. Ypatingais atsitikimais automatinis pabūklas gali büti naudojamas nepridengtiems, ypatingai svarbiems taikiniams šaudyti: kulkosvaidžiu lizdai, sekyklos, prieštankiniai pabūklai ir t. $t$."16 Nors ir kalbama apie ypatingus atsitikimus, neturint kitos artilerijos, šaulių bataliono vado žinioje esantys automatiniai pabūklai mūšio metu dažniausiai buvo naudojami batalionui didžiausią grèsmę keliantiems taikiniams - tankams ir šarvuočiams bei minétiems nedengiamiems objektams - naikinti ir gadinti. Labai rimta problema Lietuvos kariuomenès pèstininkų divizijose buvo ne tik prieštankinių priemonių trūkumas, bet ir netinkamas jų paskirstymas. Kaip jau minėta, vienintelè prieštankinè ugnies priemonè - automatiniai pabūklai - buvo per-

14 T. Jurga, Obrona Polski 1939, Warszawa, s. 254.

15 Н. М. Скоморохов, В. Н. Чернецкий, Тактика в боевых примерах. Авиационный полк, Москва, 1985.

16 Pèstininku statutas, D. II, Kautynès, Kaunas, 1939, str. 42, p. 32. 
duoti šaulių batalionams, dažniausiai juos paliekant bataliono vado žinioj, o savarankiškoms užduotims atlikti (priešlèktuvinei tiltų, siaurų perejjų ir kitų panašių objektų apsaugai, kurios metu jie neišvengiamai nutols nuo savo tiesioginių viršininkų) skiriamos rečiau ${ }^{17}$. Lenkijos divizijų prieštankinè artilerija buvo sutelkta pėstininku pulku prieštankinėse kuopose ${ }^{18}$. Vokiečiu pèstininkų divizijos prieštankiniai pabūklai buvo telkiami tiek divizijos, tiek pėstininkų pulkų prieštankinèse kuopose ${ }^{19}$. Sovietų Sajungos šaulių divizijoje prieštankinių pabūklų turejo ir divizijos prieštankinis divizionas, ir šaulių pulkų prieštankinès baterijos, ir šaulių batalionų prieštankiniai būriai ${ }^{20}$. $\mathrm{O}$ Lietuvos kariuomenèje nei pėstininkų pulko, nei divizijos vadas savo žinioje specializuotų prieštankinių priemonių neturejjo ${ }^{21}$. Todèl prieštankinèmis priemonėmis praktiškai buvo neịmanoma atlikti jokio manevro, sudaryti jų rezervo, padidinti jų tankio ar sutelkti ugnies didžiausią tankų puolimo grèsmę keliančiose vietose. Atsižvelgiant į APK patirtị galima teigti, kad minèti dalykai yra kritiniai prieštankinès gynybos galios ir atsparumo rodikliai: , Stiprūs rezervai divizijos vadu žinioje leido jiems plačiai manevruoti mūšio lauke prieštankinèmis priemonèmis ir sudaryti nepereinamas priešo tankams ugnies užtvaras ten, kur iškildavo didžiausia prasiveržimo grésmè. "22

Apie prieštankinių priemonių ugnies telkimą organizuojant bet kokius kovos veiksmus rašo ir vokiečių generolas E. Middeldorfas, karo metu buvęs Vokietijos sausumos kariuomenės generalinio štabo referentas taktikos patirčiai apibendrinti, po karo išleistame darbe karo veiksmams Rytų fronte aptarti23.

Nèra pagrindo manyti, kad to Lietuvos kariuomenès vadovybé nesuprato. Esu ịsitikinęs, kad tokia padètis susidarè tik dèl piniginių lèšų stygiaus ir kad ateityje būtų buvę imtasi priemonių prieštankinei ir priešlèktuvinei gynybai plètoti. Iki šiol klausimas apie planuotą prieštankinès ir priešlèktuvinès ginkluotès stiprinimą buvo arba visai nenagrinètas, arba paliestas tik paviršutiniškai. Savo straipsnyje šią temą pajudino iš mirties taško doc. dr. V. Lesčius, pateikdamas duomenis apie numatytus pėstininkų pulko organizacinius pakeitimus įtraukiant naujų tipų ginkluotę, tinkamą kovai su šarvuota techni-

17 Ten pat.

18 http://wp39.struktury.net/pulk-piechoty.html

19 M. Bryja, Piechota niemiecka 1939-1945, s. 15.

20 А. Б. Широкорад, Энциклопедия отечественной артиллерии, Минск, 2000, с. 609-610.

21 Štabų žinynas, Kaunas, 1938.

22 Под общей редакцией профессора генерала-армии А. И. Радзиевского. Тактика в боевых примерах. Дивизия, Москва, 1976, с. 112.

23 Э. Миддельдорф, Русская кампания: тактика и вооружение, Санкт-Петербург, 2000. 
$\mathrm{ka},-20 \mathrm{~mm}$ automatinius pabūklus BSV ir $47 \mathrm{~mm}$ prieštankinius pabūklus, kurie buvo telkiami atskiruose būriuose ir perduodami pėstininkų pulko vado žinion ${ }^{24},-$ bei formuojant priešlèktuvines motorizuotąsias kuopas ${ }^{25}$. Iš esmès beveik visus su priešlèktuvine pèstininkų gynyba susijusius ir bent jau man nežinomus klausimus doc. dr. V. Lesčius aptare minèto straipsnio skyriuje, skirtame Priešlèktuvinès apsaugos rinktinei ${ }^{26}$. Gaila, tačiau taip ir liko neatsakytas klausimas, kiek buvo užsakyta $20 \mathrm{~mm}$ automatinių pabūklų, autoriaus pavadintų BSV, kiek ir kada jų gavo Lietuvos kariuomenè. Be to, kiek diskutuotinas atrodo ir pats pavadinimas - BSV. Pvz., V. Statkus nurodo, kad „mūsu kariuomeneje jie buvo vadinami LAP (lèktuvinis automatinis pabūklas) vardu“27, ši terminą vartoja ir V. Lesčius kituose straipsnio skyriuose.

Žiūrint iš šiandienos perspektyvos, Kariuomenès štabo I skyriaus pranešimas kariuomenès vadovybei $1940 \mathrm{~m} .^{28}$, kuriame rekomenduojama aprūpinti divizijas prieštankinėmis ir priešlèktuvinėmis priemonèmis, padidinti ju judrumą, atrodo visiškai teisingas. Kaip matyti iš doc. dr. V. Lesčiaus pateiktų dokumentų, būtinybę eiti tokiu pat keliu - kariuomenę aprūpinti automatiniais, prieštankiniais, priešlèktuviniais ginklais ir labiau motorizuoti - Lietuvos kariuomenès vadovybè suvokè ir prieš prasidedant APK ${ }^{29}$.

Keistokas atrodo nuolat kartojamas pageidavimas atsisakyti didelio skaičiaus „,archajišku“ divizijų ir turèti 3-4 modernias, gerai ginkluotas divizijas $^{30}$. Iš karto kyla klausimas - o kada Lietuvos kariuomenejje buvo daugiau nei 3-4 divizijos? Juk ir IV divizijos buvo tik užuomazga.

Manyčiau, kad tarpukario Lietuvos kariuomenès pėstininkų istorija dar nèra visapusiškai ištirta ir aprašyta.

\section{ARTILERIJA}

Apie Lietuvos artileriją prieškariu rašyta tikrai nedaug. Todẻl minimame doc. dr. V. Lesčiaus straipsnyje maloniai nustebino informacijos ir dokumentų, susijusių su artilerijos dalinių organizavimo ir dislokavimo pokyčiais,

\footnotetext{
24 V. Lesčius, Lietuvos kariuomenès organizavimo, dislokavimo ir ginkluotès pokyčiai 1938-1940 m.// Karo archyvas, t. XXIV, 2009, p. 137-138.

25 Ten pat, p. 192.

26 Ten pat, p. 191-195.

27 V. Statkus, Lietuvos ginkluotosios pajègos 1918-1940 metais, p. 538.

28 V. Lesčius, Lietuvos kariuomenès organizavimo, dislokavimo ir ginkluotès pokyčiai 1938-1940 m. // Karo archyvas, t. XXIV, 2009, p. 141.

29 Ten pat.

30 Ten pat.
} 
gausa. Diskutuotina pasirode kita straipsnio dalis. Pateikdamas artilerijos priemonių Lietuvoje skaičių, autorius pasirinko išeivijos šaltinị (Baltijos valstybės kariniu požiūriu, Karys, Niujorkas, 1984, Nr. 1, p. 23):

„Lauko artilerijoje buvo per 120 patranku, suskirstyta i 10 grupiu. Dauguma patranku buvo pasenusios: prancūziškos $75 \mathrm{~mm}$ Schneider Nr. 97 ir rusiškos 75 mm Putilov Nr. 02. Sunkiojoje artilerijoje buvo 48 pabūklai šešiose grupèse. Tai buvo $155 \mathrm{~mm}$ ir $105 \mathrm{~mm}$ vokiečiu haubicos. Rezerve dar turèta anglišku $127 \mathrm{~mm}$ ir prancūzišku $155 \mathrm{~mm}$ kalibro Schneider pabūklų. “31

Kaip jau minèjau, išeivijos leidiniai dažniausiai naudojo šaltinius, paremtus ne dokumentais, kurie buvo likę okupuotoje Lietuvoje, o asmeniniais, neretai ir kitų asmenų, tiesiogiai nesusijusių su minimais įvykiais, atsiminimais, todèl jie kai kuriais atvejais nèra patikimi. Pvz., minètame šaltinyje prancūziškos ir rusiškos lauko patrankos ịvardytos taip, kaip Lietuvos kariuomeneje jos vadinamos nebuvo. Remiantis Artilerijos statutu, šios patrankos turètuc būti vadinamos $75 \mathrm{~mm} 1897 \mathrm{~m}$. patranka ${ }^{32}$ ir $76 \mathrm{~mm} 1902 \mathrm{~m}$. patranka $^{33}$. Nepaminèta esminè aplinkybė - kad rusiškos 76 mm $1902 \mathrm{~m}$. patrankos buvo naudojamos tik raitosios artilerijos. Nepaminètos nei angliškos 84 mm patrankos ${ }^{34}$ „Vickers“, nei prancūziškos $105 \mathrm{~mm} 1934 \mathrm{~m}$. haubicos ${ }^{35}$ „Shneider“. Minimos 155 ir 105 mm vokiškos haubicos, kurių Lietuvos kariuomeneje nagrinejamu laikotarpiu taip pat nebuvo. $155 \mathrm{~mm}$ kalibro artilerijos sistemų Vokietijos kariuomenè niekada negamino ir nebuvo ịtraukusi i savo ginkluotę, išskyrus trofejjines prancūziškas. Neaišku, kada ir kaip iš kariuomenès ginkluotès buvo išimti ir parduoti $127 \mathrm{~mm}$ angliški pabūklai, taip pat paminèti nurodytame šaltinyje. Paminètos „Shneider“ $155 \mathrm{~mm}$ haubicos, kurių turëjo tik 2 (jos 1920 m. iš Lenkijos kariuomenès buvo paimtos kaip trofejjai). Pasak plk. V. Šliogerio, taikos metu šios haubicos laikytos Ginklavimo valdybos sandèliuose Šančiuose, maždaug 1939 m. buvo atgabentos i Šiaulius ir pastatytos mokomosios grupès patrankų garaže, joms prižiūrèti nebuvo skirta nei tarnybos, nei etatų ${ }^{36}$. Tačiau su karo istorija susijusių daiktų kolekcininkų interneto svetainėje esama nuotraukų, kuriose šios prancū-

\footnotetext{
31 Ten pat.

32 Artilerijos statutas. D. 4: Pabūklai ir šaudmenys: a) $75 \mathrm{~mm} 1897 \mathrm{~m}$. patranka. A-53, Kaunas, 1938 .

33 Artilerijos statutas. D. 4: Pabūklai ir šaudmenys: b) 76 mm 1902 m. patranka. A-53b, Kaunas, 1939.

34 Artilerijos statutas. D. 1: Rikiuotè: a) 75 (76 ir 84) mm patrankos. A-50, Kaunas, 1938.

35 Artilerijos statutas. D. 4: Pabūklai ir šaudmenys: c) $105 \mathrm{~mm} 1934 \mathrm{~m}$. haubica. A-53c, Kaunas, 1939. Artilerijos statutas. D. 1: Rikiuote: b) $105 \mathrm{~mm} 1934$ m. haubica. A-50b, Kaunas, 1940.

36 V. Statkus, Lietuvos ginkluotosios pajègos 1918-1940 metais, p. 102.
} 
ziškos $155 \mathrm{~mm}$ haubicos įamžintos šaudymo pratybų metu ${ }^{37}$. Dar keisčiau atrodo minètos 6 sunkiosios artilerijos grupè ${ }^{38}$, nes visi kiti šaltiniai pabréžia, kad sunkiosios artilerijos Lietuvos kariuomenė 1938-1940 m. apskritai neturejjo. Šios ginkluotès buvo užsakyta, tačiau iki sovietinès okupacijos taip ir negauta. Todèl manau, kad naudotame šaltinyje nurodytas visai kito laikotarpio, o ne straipsnyje minimu 1938-1940 m. artilerijos kiekis, be to, kartu su mano pastebètais netikslumais. Todèl, mano nuomone, kaip šaltinis apie Lietuvos kariuomenès artileriją labiau tinkamas plk. ltn. dr. G. Surgailio darbas, kuriame nurodyti Lietuvos kariuomenès $1940 \mathrm{~m}$. turètų artilerijos pabūklų kiekiai ir tipai ${ }^{39}$. Nors ir šiame šaltinyje yra neaiškių, diskutuotinų klausimų. Pvz., paminètos keturios $105 \mathrm{~mm}$ patrankos, įvardytos kaip „Škoda P.z.1“40. Žymens „P.z.“ iki šiol neteko matyti nei „Škodos“, nei kitų gamintojų artilerijos sistemų pavadinimuose. Greičiau būtų galima tikètis „VZ.“ - čekiško „Vzor“441, vartoto visai Čekoslovakijos kariuomenès ginkluotei žymèti. Iš 105 mm kalibro galima spèti, kad tai - „hrubý kanon vz. 35“, vienintelès tuo metu gamintos šio kalibro čekiškos patrankos. Deja, nei tikslesnių duomenų, nei šaltinio G. Surgailis nepateikè. Tas ir neturètų stebinti atsižvelgiant ị tai, kad minètas G. Surgailio darbas išleistas prieš 12 metų, kai nebuvo nei interneto, nei galimybių taip laisvai, kaip šiandien, naudotis kitu šalių šaltiniais. Remiantis buvusio kariuomenès vado div. gen. S. Raštikio ${ }^{42}$ ir gen. št. plk. A. Šovos ${ }^{43}$ atsiminimais, Čekoslovakijoje užsakytos sunkiosios artilerijos priemonès, už kurias ten buvo sumokèta ir kurių Vokietija neleido vežti tranzitu per savo teritoriją, vẻliau buvo parduotos Rumunijai. Tačiau vieninteliai nauji čekiški sunkiosios artilerijos pabūklai, tuo metu įtraukti i Rumunijos kariuomenès ginkluotę, buvo 149 mm haubicos „Škoda model 1934“ (dar vadinamos K1 arba K serijos haubicomis) ${ }^{44}$.

Tai kokių gi sunkiosios artilerijos pabūklų buvo užsakyta Čekoslovakijoje? Kiek ir kada? Jeigu tokių pabūklų buvo užsakyta, kodèl Kariuomenės štabo IV skyriaus viršininko gen. št. plk. B. Gertaus 1940-05-18 slaptame

\footnotetext{
37 www.militaria.lt

38 V. Lesčius, Lietuvos kariuomenès organizavimo, dislokavimo ir ginkluotès pokyčiai 1938-1940 m. // Karo archyvas, t. XXIV, 2009, p. 146.

39 G. Surgailis, Lietuvos kariuomenè 1918-1998, p. 57.

40 Ten pat.

41 Liet. ,pavyzdys“.

42 S. Raštikis, Kovose dèl Lietuvos, Vilnius, 1990, p. 530.

43 V. Statkus, Lietuvos ginkluotosios pajègos 1918-1940 metais, p. 102-103.

44 http://www.worldwar2.ro/arme/?section $=18$
} 
rašte kariuomenès vadovybei ${ }^{45}$ kalbama apie būtinybę įisigyti 40 prancūziškų 155 mm 1917 m. haubicų? Drịsčiau teigti, kad klausimai, susiję su Lietuvos kariuomenès artilerija, ypač su sunkiosios artilerijos pirkimo aplinkybėmis, Lietuvos istorikų išsamiai neišnagrinèti.

\section{KAVALERIJA}

Lietuvos kariuomenès kavalerija, kaip ir artilerija, - vis dar labai mažai tirta Lietuvos kariuomenès ginklų rūšis. Ir vèl galima pasidžiaugti informacijos, pateiktos doc. dr. V. Lesčiaus straipsnyje, gausa. Norètųsi aptarti kai kuriuos diskutuotinus klausimus, susijusius su Lietuvos kavalerija ir ypač su autoriaus padarytomis išvadomis.

„Prieš šia moderniają kavalerija mūsų kavalerija nei pasirengimu, nei apginklavimu, nei taktika veikti buvo nepasiruošusi ir bent kiek atsilaikyti nebūtu galejusi. Susidūrusi su priešo šarvuočiais ir aviacija, ji būtų išblaškyta, kaip atsitiko lenku kavalerijai kovu su vokiečiais metu. Vokiečiu-lenku karas kaip tik i̇rode visiška senosios kavalerijos negalëjima bent kiek atsilaikyti prieš moderniaja kavalerija (šarvuočius)."“6

Su tokiu autoriaus teiginiu sutikti be išlygų negalèčiau. Kavalerijos trūkumai moderniajame kare buvo gerai žinomi visų šalių kariuomenėms. Tačiau tokių pat sunkumų kaudamiesi su dideliais šarvuočių ir mechanizuotaisiais junginiais turèjo ir pèstininkai. Vokietijos-Lenkijos karo veiksmų $1939 \mathrm{~m}$. metu lenku kavalerijos brigados buvo priverstos kautis su gerokai stambesniais šarvuotais ir motorizuotaisiais priešo junginiais - divizijomis - ir jau vien dèl to negalejo pasiekti jokių žymesnių laimejjimų. Tačiau šios brigados buvo vos ne vieninteliai mobilūs Lenkijos kariuomenès daliniai, kurie, beje, kovojo ne prasčiau nei dvi kur kas geriau prieštankiniais ginklais ir šarvuota technika aprūpintos lenkų motorizuotosios brigados. Kavalerijos brigados dažniausiai buvo vienintele priemonė armijų sparnams dengti, todèl joms teko priimti pagrindinius šarvuotų ir motorizuotų Vokietijos kariuomenès junginių, besiveržiančiu šias armijas apeiti, smūgius. Pvz., 1939 m. rugsėjo 2 d. Voluinès (Volynès) kavalerijos brigados daliniams (2 kavalerijos pulkams, šarvuotam divizionui, raitosios artilerijos divizionui, šarvuotam traukiniui Nr. 53), besiginantiems ị šiaurę nuo Klobucko, teko priimti vokiečiu 4-osios tankų divizijos smūgị. Nors mūšis vyko nuo 8 iki 17 val., brigada su-

45 V. Lesčius, Lietuvos kariuomenès organizavimo, dislokavimo ir ginkluotès pokyčiai 1938-1940 m. // Karo archyvas, t. XXIV, 2009, p. 202.

46 V. Lesčius, Lietuvos kariuomenès organizavimo, dislokavimo ir ginkluotès pokyčiai 1938-1940 m. // Karo archyvas, t. XXIV, 2009, p. 158-159. 
gebèjo išlaikyti užimtas pozicijas ir jas paliko tik kitą dieną visai „Lodzès“ armijai traukiantis. Disponuojanti kukliomis prieštankinemis priemonemis ir artilerija Voluinès kavalerijos brigada sunaikino apie 40-50 tanku $\mathrm{u}^{47}$.

O štai žymaus vokiečių tankų teoretiko generolo H. Guderiano atsiminimai, tam tikru aspektu apibūdinantys lenku kavaleriją: „Pirmu karo dienu nervingumas nakti tapo dar labiau juntamas. 2-osios motorizuotosios divizijos vadas po pusiaunakčio pranešé, kad priverstas atsitraukti dèl lenku kavalerijos spaudimo. "48

Vokietijos kariuomenès artilerija buvo sutelkta pėstininkų divizijose ir atskiruose junginiuose. Per visą APK Vokietijos pėstininkų divizija žvalgybos bataliono sudètyje pagal etatus turejo turèti kavalerijos eskadroną ${ }^{49}$. Lenkijos kare dalyvavo 1-oji kavalerijos brigada (1. Kavallerie-Brigade), $1940 \mathrm{~m}$. performuota ị didesnị jungini - 1-ają kavalerijos diviziją (1. Kavallerie-Division). Ši divizija tikrai dalyvavo ir karo veiksmuose Olandijoje $\mathrm{e}^{50}$, o ne stovejo Rytprūsiuose, kaip teigia doc. dr. V. Lesčius ${ }^{51}$. 1-oji kavalerijos divizija veiké iki $1941 \mathrm{~m}$. lapkričio, kai buvo pertvarkyta i 24-ają tankų diviziją. $1945 \mathrm{~m}$. kovą buvo suformuotos dvi - 3-ioji ir 4-oji - kavalerijos divizijos, kurios veikè iki karo veiksmu pabaigos, 1945 m. gegužès. APK metu, 1943-1944 m., Vokietijos kariuomenèje veikė 1-oji kazokų divizija (1. Kosaken-Divizion), o 1944-1945 m. - visas SS XV kazokų kavalerijos korpusas (XV. Kosaken Kavallerie Korps), sudarytas iš 1-osios ir 2-osios kazokų kavalerijos divizijų (1. Kosaken-Kavallerie-Division, 2. Kosaken-Kavallerie-Division) ${ }^{52}$. Kiti SS kavalerijos daliniai: nuo 1942 m. rugsėjo - SS kavalerijos brigada (SS-Kavallerie-Brigade), kuri $1943 \mathrm{~m}$. spalio mèn. taip pat buvo performuota i didesni jungini - 8-ają SS kavalerijos divizija „Florian Geyer“ (8. SS-Kavallerie-Division „Florian Geyer“), kuri veike iki 1945 m. Šios divizijos 17-ojo kavalerijos pulko pagrindu buvo suformuota 22-oji SS savanoriu kavalerijos divizija „Maria Theresia“ (22. SS-Freiwilligen-Kavallerie-Division „Maria Theresia“), kuri veikè nuo 1944 m. balandžio iki 1945 m. sausio, taip pat labai trumpai - 1945 kovą-balandi - veikusi 37-oji SS savanorių kavalerijos divizija (37. SS-Freiwilligen-Kavallerie-Division ${ }^{53}$ ). Mano nuomone, autoriaus

T. Jurga, Obrona Polski 1939, s. 291-293.

48 Г. Гудериан, Воспоминания солдата, Смоленск, 1998, с. 98.

49 M. Bryja, Piechota niemiecka 1939-1945, s. 14.

50 J. Ledwoch, Kawaleria niemiecka. Militaria 151, Warszawa, 2002, s 15-21.

51 V. Lesčius, Lietuvos kariuomenès organizavimo, dislokavimo ir ginkluotès pokyčiai 1938-1940 m. // Karo archyvas, t. XXIV, 2009, p. 159.

52 http://www.lexikon-der-wehrmacht.de/Gliederungen/schnelleTruppen.htm

53 http://www.lexikon-der-wehrmacht.de/Gliederungen/KavallerieDivisionenSS/Gliederung.htm 
teiginys, kad „pastarieji (kaip galima suprasti iš teksto - vokiečiai) Antrajame pasauliniame kare kavalerijos beveik išvis neturëjo" ${ }^{54}$, diskutuotinas.

Dar plačiau kavaleriją APK naudojo Sovietų Sajungos kariuomenė. Sovietine kavalerija tikrai labai išsamiai aprašyta. Labai gerai sovietų kavalerijos vaidmenį, trūkstant šarvuotosios technikos, kaip vienintelès tuo metu mobilios ginklo rūšies, galinčios apeiti priešą, ir visiškai nesant kelių, mano nuomone, liudija 1941-12-09 15.45 val. Vakarų fronto vado G. Žukovo direktyva armijoms ir Belovo grupe ${ }^{55}$, taip pat jo ir 20 -osios armijos vado A. Vlasovo pokalbių telefonu 1942-01-28 ${ }^{56}$ ir 1942-01-30, kurių metu G. Žukovas aiškina kavalerijos svarbą puolime ir duoda konkrečius nurodymus dèl jos panaudojimo, stenogramos ${ }^{57}$.

Vadinasi, kavalerija nebuvo visiškai nereikalinga, o tam tikromis sąlygomis buvo tiesiog nepakeičiama. Štai, mano nuomone, įdomus lenkų karo istoriko J. Ledwocho požiūris į vokiečių kavaleriją prieš APK: „Dèl to 1-ają kavalerijos brigada traktavo kaip tam tikra priešnuodį dèl galimybès kovoti sąlygomis, kurios kritiškai netiko pèstininkams ir motorizuotai - tanku kariuomenei. "58

Jau minèto generolo $\mathrm{H}$. Guderiano, tuo metu 2-osios tanku grupés vado, sprendimas dèl jo žinioje esančios 1-osios kavalerijos divizijos panaudojimo pradedant operacija „Barbarosa“: „Po Vakarinio Bugo forsavimo tanku grupé turejo pulti, nors dešinejje buvo sunkiai pereinamas Pripetés pelkiu rajonas $<\ldots>$ Šia dviguba grèsmę sparnams aš norejau panaikinti dviem büdais: $<\ldots>>$ - panaudodamas 1-aja kavalerijos divizija, buvusią tanku grupès sudètyje, dešiniajame sparne - pelketoje vietoveje, sunkiai įveikiamoje motorizuotiems junginiams. " ${ }^{\text {"59 }}$

Grižtant prie Lietuvos kariuomenès, reikètų pažymėti, kad jos kavalerijos pulkas turèjo tiek pat prieštankinių priemonių ir sunkiụjų kulkosvaidžių kaip Lenkijos kavalerijos pulkas, o lengvųjų kulkosvaidžių netgi du kartus daugiau. Be to, pulko turimi 2 šarvuoti automobiliai „Landsverk L-181“ 1938-1940 m. galëjo kovoti su visa potencialių priešų šarvuota technika. Dèl menkos motorizacijos ir prasto kelių tinklo Lietuvos kavalerijos pulkai buvo labai svarbi ir vienintele judri priemone kovojant su bet kurio potencialaus priešininko kariuomene, taip pat šarvuotaisiais ir motorizuotaisiais daliniais. Kavalerija sudare tik nežymią Lietuvos kariuomenès dalį, ir jai, kaip ginklo

54 V. Lesčius, Lietuvos kariuomenès organizavimo, dislokavimo ir ginkluotès pokyčiai 1938-1940 m. // Karo archyvas, t. XXIV, 2009, p. 203.

55 В. Краснов, Неизвестный Жуков, с. 283.

56 Ten pat, p. 298-301.

57 Ten pat, p. 302-303.

58 Kawaleria niemiecka. Militaria 151, Warszawa, s. 9.

59 Г. Гудериан, Воспоминания солдата, Смоленск, 1998, с. 200. 
rūšiai, jokios kitos alternatyvos 1938-1940 m., atsižvelgiant į būtinybę turèti mobilių priedangos dalinių, Lietuvos ekonomikos, motorizacijos, kelių infrastruktūros lygi, nebuvo.

Dèl arklio ir motorinès transporto priemonès panaudojimo labai įdomi ir naudinga polemika, patvirtinanti arklio, kartu, netiesiogiai, ir kavalerijos svarbą, vyko laikraštyje „Policija“60.

\section{KARO TECHNIKOS DALYS}

Neseniai pasirodžiusi V. Grigoraičio knyga ${ }^{61}$ užpildè daugelị informacijos apie Lietuvos kariuomenès techniką spragų. Daug naujų duomenų apie autotransporto, šarvuočių rinktinès organizaciją ir raidą pateikè ir doc. dr. V. Lesčius ${ }^{62}$. Tačiau tenka pripažinti, kad Lietuvos kariuomenès ryšiai ir inžinerija, ypač naudota technika, dar nėra labai gerai išnagrinèta sritis.

\section{Ryšiai}

Ryšiai kariuomenèje visais laikais buvo labai svarbūs. Apie ryšių dalinių organizacinę struktūrą ir kaitą, jos vadus rašyta pakankamai, o apie ryšių darbo organizavimą ir techniką informacijos tikrai trūksta. Ryšių technika gana plačiai aptarta V. Statkaus ${ }^{63}$, tačiau vẻlesniuose leidiniuose ši informacija tik pakartota. Ypač plačiai aprašytos didžiosios kariuomenès stotys UFI $75^{64}$. O apie kitas kariuomenès radijo stotis - prancūziškas ER 400, angliškas automobilines, vidutines „V“ tipo, mažąsias „M“ tipo, prancūziškas ir angliškas „Duplex“, „I“ tipo imtuvus ar kavalerijos „E“ tipo, vaizdinius telegrafo aparatus, telefono aparatus ir komutatorius šiek tiek informacijos galima rasti tik jau minètame V. Statkaus darbe, Štabų žinyne ${ }^{65}$ ir G. Surgailio knygoje ${ }^{66}$. Be to, ši informacija - tai daugiausia turètų ryšio priemonių kiekis ir jų paskirstymo daliniuose duomenys.

Galbūt tai jokia naujiena profesionaliems istorikams, tačiau man neteko matyti išspausdintų ar nurodytų „Karo technikos sąrašųu"67, todèl noréčiau pa-

60 Policija, Kaunas, 1939.

61 V. Grigoraitis, Lietuvos kariuomenès technika 1918-1940, Vilnius, 2009.

62 V. Lesčius, Lietuvos kariuomenès organizavimo, dislokavimo ir ginkluotès pokyčiai 1938-1940 m. // Karo archyvas, t. XXIV, p. 174-179.

63 V. Statkus, Lietuvos ginkluotosios pajègos 1918-1940 metais.

64 Ten pat, p. 298-299.

65 Štabų žinynas, Kaunas, 1938.

66 G. Surgailis, Lietuvos kariuomenè 1918-1998, p. 50.

67 Karo technikos sąrašai, Kaunas, 1939. 
teikti kai kuriuos radijo ryšio technikos, paminètos šiame šaltinyje, duomenis.

Pirmiausia labiausiai mane asmeniškai sudomino automobilinè radijo stotis „Gambrell Bross a. Co. Ltd.“ 490 tipo. Šią radijo stotị sudarè: 556 tipo siųstuvas (su 3 lempomis), 558 tipo imtuvas (su 4 lempomis), 1 telefono aparatas (toliau - TA) ir benzininis agregatas HT 8/5. Labai gaila, tačiau pagrindiniai techniniai duomenys - galingumas, diapazonas, kanalų skaičius, veikimo tolis ir pan. - šiame šaltinyje nenurodyti. Nenurodytas ir automobilio tipas, tačiau iš kitų šaltinių, pvz., V. Grigoraičio darbų ${ }^{68}$, žinome, kad tai angliškas 6x4 „Morris Commercial DC“ automobilis. Jam priklausė suktuvas su lynu ir ant padangų uždedami vikšrai ${ }^{69}$.

D tipo radijo ryšio įrenginiai nurodyti kaip ER 400 ir UFI 75 stotys. Kadangi UFI 75 stotis išsamiai aprašyta, pateiksiu tik kai kuriuos ER 400 duomenis. Šią stotị sudaro siųstuvas (su 1 lempa) ir imtuvas (su 1 lempa), 1 telefono aparatas, benzininis variklis, dinamo mašina ir $14 \mathrm{~V}$ akumuliatoriaus baterija. Stotis pervežama specialiu vežimu ${ }^{70}$.

V tipo radijo stotys buvo 2 firmų - „Marconi“ ir „Gambrell“ - gamybos. Šių stočių techniniai duomenys nepateikti, tačiau iš to, kad neminimas telefono aparatas, galima spręsti, jog jomis buvo galima dirbti tik naudojant raktą, t. y. telegrafo būdu. Taigi tiesioginis telefoninis pokalbis buvo neįmanomas. Kiekviena iš šių stočių buvo pervežama specialiu poriniu vežimu ${ }^{71}$.

Radijo stotys „Duplex“ taip pat V. Statkaus paminetos ${ }^{72}$. „Karo technikos sąrašuose“ nurodyta, kad jos buvo 3 tipų: angliškos „Marconi“ ir „Gambrell“" ir prancūziškos SFR. Šios stotys buvo nešiojamosios, kiekvieną iš jų sudarè siųstuvo dèžè ir imtuvo dèžè. Nurodyta, kad „Marconi“ stotis neturi mikrofono, todèl darytina prielaida, jog ja galima buvo dirbti tik telegrafo būdu. Kitų techninių duomenų nepateikta ${ }^{73}$.

Manau, kad Lietuvos kariuomenès ryšiai dar sulauks istorikų dėmesio. Šiuo metu paskelbtos informacijos nepakanka netgi to meto Lietuvos kariuomenès ryšių priemonėms ir struktūroms su kitų šalių kariuomenių atitinkama sritimi palyginti.

68 V. Grigoraitis, Lietuvos kariuomenès technika: sunkvežimiai // Karo archyvas, t. XVI, p. 179-180.

69 Karo technikos sąrašai, Kaunas, 1939.

70 Ten pat.

71 Ten pat.

72 V. Statkus, Lietuvos ginkluotosios pajëgos 1918-1940 metais, p. 300.

73 Karo technikos sąrašai, Kaunas, 1939. 


\section{Inžinerija}

Pirmasis Lietuvos kariuomenès inžineriją aprašè V. Statkus ${ }^{74}$. Naujos ir ìdomios informacijos, nors gana lakoniškai, pateikè doc. dr. V. Lesčius ${ }^{75}$. Ypatingo dèmesio verti pionierių dalinių motorizacijos ir jų veiklos vertinimo per 1938 ir 1939 m. manevrus duomenys ${ }^{76}$. Tačiau beveik visiškai nerasime žinių apie naudotą karo inžinerijos techniką ir turtą.

\section{3. Šarvuočių rinktinė}

Lietuvos kariuomenès Šarvuočių rinktinė ir šarvuočiai aprašyti gana išsamiai. Tradiciškai pirmą tenka paminèti V. Statkų. Labai išsamiai Lietuvos kariuomenès techniką aptarè V. Grigoraitis neseniai išleistame darbe „Lietuvos kariuomenès technika“77. Labai daug naujo galima rasti ir minètame doc. dr. V. Lesčiaus straipsnyje ${ }^{78}$. Mano nuomone, pastarasis autorius yra pirmas istorikas, kuris, remdamasis dokumentais ir Vokietijos-Lenkijos karo patirtimi, pateike Šarvuočių rinktinès ir jos galimybių vykdyti galimus karo veiksmus vertinimą. Nors per APK daugiausia kiekybinių ir kokybiniu pokyčių patyrẻ tankų (šarvuočių) ir motorizuotieji/mechanizuotieji daliniai, Lietuvos sąlygomis formuoti didelių šarvuotų dalinių buvo neịmanoma dèl ịvairių priežasčių: ekonomikos silpnumo, žemo motorizacijos lygio, techniškai gerai parengtų kadrų trūkumo, ribotų galimybių įsigyti tik kitose šalyse gaminamos specialiosios ir kovos technikos.

\section{KARO AVIACIJA}

Kaip istorikas mėgèjas, neturejęs galimybès ištisai dirbti Lietuvos valstybès centriniame ir kituose archyvuose, esu labai dèkingas visiems karo istorijos tema rašantiems ir plačiajai visuomenei archyvinius dokumentus pristatantiems profesionaliems istorikams. Visų pirma dr. A. Liekiui, kurio kontroversiškoje monografijoje „Lietuvos karo aviacija 1919-1940“79 gausiai

\footnotetext{
74 V. Statkus, Lietuvos ginkluotosios pajègos 1918-1940 metais, p. 300.

75 V. Lesčius, Lietuvos kariuomenès organizavimo, dislokavimo ir ginkluotès pokyčiai 1938-1940 m. // Karo archyvas Nr. XXIV, p. 164-168.

76 Ten pat, p. 165 .

77 V. Grigoraitis, Lietuvos kariuomenès technika 1918-1940, Vilnius, 2009.

78 V. Lesčius, Lietuvos kariuomenès organizavimo, dislokavimo ir ginkluotès pokyčiai 1938-1940 m. // Karo archyvas, t. XXIV, p. 174-179.
}

79 A. Liekis, Lietuvos karo aviacija 1919-1940, Vilnius, 1999. 
pateikta iki šiol neskelbtų archyvinių dokumentų. Kol kas tai didžiausios apimties darbas, kuriame galima rasti daugiausiai atsiminimų ir dokumentinès informacijos apie Lietuvos karo aviaciją. Lakoniškos ir tikslios informacijos apie Lietuvos karo aviacijos organizaciją ir jos sudèti 1940 m. nemažai plk. ltn. dr. G. Surgailio darbe ${ }^{80}$. Labai turiningi ir ịdomūs G. Ramoškos darbai, kuriuos net sunku išvardyti, verta paminèti ir Lietuvos aviacijos entuziasto N. Korbuto interneto svetainę, skirtą 1919-1940 m. Lietuvos aviacijai ${ }^{81}$. Tačiau dauguma autorių nepateikia savo išvadų apie šios kariuomenès rūšies pajègumą, būklę. O minètame doc. dr. V. Lesčiaus straipsnyje tokios vertinamosios išvados padarytos ${ }^{82}$. Kadangi dauguma atsiminimų ir rašinių apie Lietuvos karo aviaciją labiau grịsti entuziazmu ir emocijomis nei istoriniais faktais, tiek Lietuvos karo aviacija, tiek jos turèta technika ir asmeninè sudètis vertinama itin aukštai. Doc. dr. V. Lesčiaus straipsnyje pateikti dokumentai sudaro prielaidas i šiuos klausimus pažvelgti visiškai kitaip ${ }^{83}$. Tačiau kai kurios autoriaus išvados ir vertinimai, mano nuomone, yra diskutuotini. Labai įdomu paanalizuoti šios straipsnio dalies išnašas. Visuose čia pateiktuose šaltiniuose, datuojamuose iki $1939 \mathrm{~m}$. rugsèjo, rašoma tik apie esamą aviacijos materialinę ir personalo sudètį, aerodromų įrengimą. O visi kiti, kuriuose vertinama aviacijos būklè ir perspektyvos, išleisti vèliau, pradedant 1939 m. lapkričiu, t. y. jau pasibaigus Vokietijos ir Lenkijos karo veiksmams. Kaip jau minejjau, po Lenkijos pralaimėjimo Lietuvos kariuomenėje, kaip ir kitų šalių kariuomenèse, buvo padaryta daug skubotų išvadų. Drįstu teigti, kad norint įvertinti Lietuvos karo aviaciją neužtenka vadovautis vien autoriaus naudotais Lietuvos kariuomenès archyviniais dokumentais. Tam būtina ir šalių - potencialių Lietuvos Respublikos priešininkių 1938-1940 m. (Lenkijos, Vokietijos ir Sovietų Sajungos) - karinių oro pajègų lyginamoji ir aviacijos panaudojimo APK metu patirties analizè. Tai padaryti išsamiai ir aiškiai šiame straipsnyje sudètinga, todèl savo nuomonę išdèstysiu labai glaustai.

Kaip minejau, mano nuomone, negalima vertinti Lietuvos karo aviacijos iki 1939 m. rudens nepalyginus jos su Lenkijos karo aviacija. Kadangi Lietuvos karo aviacijos organizacija ir technika jau nagrinètos mano anksčiau pristatytuose šaltiniuose, trumpai apibūdinsiu Lenkijos karo aviaciją.

Nors 1938 m. kovo ménesi Lenkijos, kuri buvo paskelbusi ultimatumą Lie-

${ }^{80}$ G. Surgailis, Lietuvos kariuomenè 1918-1998.

81 www.plienosparnai.lt

82 V. Lesčius, Lietuvos kariuomenès organizavimo, dislokavimo ir ginkluotès pokyčiai 1938-1940 m. // Karo archyvas, t. XXIV, 2009, p. 178-191.

83 Ten pat. 
tuvai, karo aviacijos pajėgos buvo didžiausios per visą jų istoriją (jas sudare 53 eskadros ir 464 koviniai lèktuvai), jų būklè (kokybė) buvo apverktina: „Lietu$v s^{84}$ ir Zaolzès ${ }^{85}$ operacijos labai aiškiai parode aviacijos operatyvini silpnuma. Per akcija Zaolzejje paaiškejo, kad labai seni R-XIII ${ }^{86}$ netinka kovos veiksmams ir ju trūksta „Karaś" ${ }^{\text {"87 }}$ remontuojamiems orlaiviams pakeisti (daugelyje linijiniu eskadru lèktuvu skaičius sumažëjo iki 6-7). Dèl to laikinai 1938 m. pabaigoje visos 18 R-XIII eskadru buvo perkeltos į antraja linija <... > Anksčiau 3 „Fokker"88 bombonešiu eskadros buvo perkeltos ị antraja linija, kad véliau būtu perginkluotos „Łos" ${ }^{\prime 89}<\ldots>$ Dar blogiau, 1938 m. pradžioje pastebèta daugybe vietinès gamybos plieniniu variklio „Mercury“IV ir V atramu ìtrūkimu P.1190. Kova kreiptasi i anglu kompanija „Bristol“"1, kad būtu kiek galima greičiau pagaminta 150 tokiu atramu ir atsiusta ị šali apdirbti. <...> Atramos pradetos siųsti partijomis jūros keliu spalio men. ir baigtos siusti 1939 m. sausio mèn. Esant naikintuvu technikos praradimo grèsmei, P.11 turëjo būti naudojami labai atsargiai. ${ }^{\text {"92 }}$

Dar reikia atsižvelgti ị tai, kaip $1938 \mathrm{~m}$. Lenkijos karo aviacija buvo padalyta - ją sudare 5 pulkai ir 1 pulko dydžio aviacijos grupė Varšuvoje. Iš šių dalinių prieš Lietuvą realiai galejo veikti tik 5-asis pulkas Lydoje, turintis viso labo 2 naikintuvų eskadras (10 P.11 ir 10 beviltiškai pasenusių P.7), 1 eskadrą linijinių PZL.23B „Karaś“ (10 lèktuvų) ir 2 žvalgybos eskadras (14 Lublin R-XIII), sustiprintas atskiromis eskadrilèmis. Be to, galimų karo veiksmų su Lietuva metu šis pulkas dar turëjo vykdyti Vilniaus krašto priešlejktuvinę gynybą ir žvalgybą pasienyje su Sovietų Sajunga. Ir šiaip nedidelès pajėgos veikè dideleje teritorijoje neturèdamos galimybių laiku padengti kovinių ir eksploatacijos nuostolių.

Trumpai apžvelkime ir palyginkime Lenkijos ir Lietuvos lèktuvų svarbesnius techninius lentelèje pateiktus duomenis.

\footnotetext{
84 Lenkijos kariuomenès veiksmai, susiję su ultimatumo Lietuvai paskelbimu.

85 Lenkijos kariuomenès įvedimas į Čekoslovakijos teritoriją $1938 \mathrm{~m}$.

86 Lenkų žvalgybinis lèktuvas Lublin R-XIII.

87 Lenkų linijinis, t. y. žvalgybinis lèktuvas - lengvasis bombonešis PZL P.23B „Karaś“.

88 Olandų gamybos transportinis lèktuvas „Fokker“ F.VII/3m, Lenkijos karo aviacijoje vadintas bombonešiu, tačiau nuo $1936 \mathrm{~m}$. naudojamas tik kaip transportinis ir parašiutininkams rengti.

89 Bombonešis PZL P.37 „Łoś“, moderniausias ir greičiausias lenkų lèktuvas prieš APK.

90 Pagrindinis Lenkijos karo aviacijos naikintuvas (P.11a ir P.11c modifikacijos).

91 Didžiosios Britanijos aviacinès technikos kompanija, viena pagrindinių to meto variklių gamintojų.
}

92 J. B. Cynk, Siły lotnicze Polski i Niemiec. Wrzesień 1939, Warszawa, 1989, s. 80-81. 


\begin{tabular}{|l|c|c|c|c|}
\hline & $\begin{array}{c}\text { Didžiausias } \\
\text { greitis, } \mathrm{km} / \mathrm{h}\end{array}$ & $\begin{array}{c}\text { Variklis, } \\
\mathrm{AG}\end{array}$ & $\begin{array}{c}\text { Pabūklų ir } \\
\text { kulkosvaidžiu }\end{array}$ & $\begin{array}{c}\text { Bombų, } \\
\mathrm{kg}\end{array}$ \\
\hline Naikintuvai & & & & \\
\hline Dewoitine D 501L & 360 & 860 & $\begin{array}{c}1 \times 20 \mathrm{~mm} \\
2 \times 7,92 \mathrm{~mm}\end{array}$ & nèra \\
\hline Fiat CR.20 & 260 & & $2 \times 7,7 \mathrm{~mm}$ & nèra \\
\hline PZL P.11c & $360-375$ & 550 & $2-4 \times 7,92 \mathrm{~mm}$ & $4 \times 12,5$ \\
\hline PZL P.11a & 343 & 605 & $2 \times 7,92 \mathrm{~mm}$ & $4 \times 12,5$ \\
\hline PZL P.7 & 327 & 485 & $2 \times 7,92 \mathrm{~mm}$ & nèra \\
\hline $\begin{array}{l}\text { Žvalgybiniai lengvieji } \\
\text { bombonešiai }\end{array}$ & & & & \\
\hline ANBO 41 & 340 & 910 & $3-4 \times 7,92 \mathrm{~mm}$ & 200 \\
\hline ANBO IV & 280 & 590 & $4 \times 7,92 \mathrm{~mm}$ & 144 \\
\hline Ansaldo A 120 & 240 & & $3 \times 7,7 \mathrm{~mm}$ & 250 \\
\hline PZL .23B „Karas““ & 319 & 680 & $4 \times 7,92 \mathrm{~mm}$ & $\begin{array}{c}\text { prakt. } 400 \\
\text { maks.700 }\end{array}$ \\
\hline Lublin R-XIIID & 185 & 220 & $1 \times 7,92 \mathrm{~mm}$ & ne்ra \\
\hline
\end{tabular}

Kaip matyti iš pateiktos lentelès, Lenkijos karo aviacijos lèktuvų, ypač naikintuvų, techniniai duomenys nesuteike jiems jokio kokybinio pranašumo, o dèl aviacijos regioninio dislokavimo ir pavaldumo nebuvo imanoma pasiekti ir aiškios kiekybinès persvaros. Be to, seni lenkų naikintuvai neturejo radijo stočių, jos buvo ịrengtos tik kas trečiame P.11 ${ }^{93}$. Remdamasis šiais duomenimis daryčiau prielaidą, kad kovo mènesi Lietuvos karo aviacijos žvalgybiniai lèktuvai ANBO IV ir ypač ANBO 41, kurie „Kariuomenès štabo III skyriaus nuomone, $<$...>savo paskirčiai visai netiko" ${ }^{\text {(94 }}, 1938$ m. kovą galejjo veikti efektyviai praktiškai nesitikẻdami sutikti priešo naikintuvų, taip pat kaip ir Lenkijos žvalgybiniai orlaiviai. Be to, ginkluoti didesnio kalibro bombomis (ANBO IV ir ANBO 41 galèjo pakelti ne didesnes kaip 12,5 kg bombas) PZL.23B „Karaś“ ${ }^{“ 95}$. Tačiau ir linijiniai PZL.23B „kèle““ tik ne didesnes kaip $100 \mathrm{~kg}$ bombas, skraidè nedideliu greičiu ir negalejjo vykdyti „tikrų“ bombonešių užduočių. 1936 metais lenkai apskaičiavo, kiek reikia bombų svarbiems taikiniams sunaikinti. Jų skaičiavimais, vienam tiltui pikiruojant visiškai sunaikinti reikia 24 vnt. 300 kg bombų, $1000 \times 500$ m bėgių - 320 vnt. 50 kg bombų. Pikiruoti vienintelis jų turimas „bombonešis“

93 J. B. Cynk, Siły lotnicze Polski i Niemiec. Wrzesień 1939.

94 V. Lesčius, Lietuvos kariuomenès organizavimo, dislokavimo ir ginkluotès pokyčiai 1938-1940 m. // Karo archyvas, t. XXIV, p. 188.

95 J. B. Cynk, Siły lotnicze Polski i Niemiec. Wrzesień 1939, s. 180. 
PZL P.23 negalejjo, lèktuvų, galinčių nešti $300 \mathrm{~kg}$ bombas, taip pat neturëjo ${ }^{96}$.

Itraukus i ginkluotę ANBO VIII, Lietuvos karo aviacija būtų sustiprëjusi kiekybiškai ir kokybiškai. Iki 1942 metų šio tipo lèktuvas būtų buvęs gana greitas ir veiksmingas ginklas prieš Lenkijos karo aviaciją ${ }^{97}$, o jo greitis pakankamas (laikotarpiu iki 1941 m.) kovoti su Sovietų Sajungos karinėmis oro pajëgomis. Tai lėmé beviltiškai „,buksavusi“ Lenkijos karo aviacijos plètros ir SSRS naujų tipų lèktuvų kūrimo ir gamybos programos ${ }^{98}$. Šioje lentelëje pateikiami Lietuvos, Lenkijos, SSRS ir Vokietijos naikintuvų duomenys:

\begin{tabular}{|l|c|c|c|c|c|c|}
\hline Naikintuvai & Metai & $\begin{array}{c}\text { Didžiausias } \\
\text { greitis, km/h }\end{array}$ & $\begin{array}{c}\text { Variklis, } \\
\text { AG }\end{array}$ & $\begin{array}{c}\text { Pabūklų } \\
\text { ir kulko- } \\
\text { svaidžių }\end{array}$ & $\begin{array}{c}\text { Bombų, } \\
\text { kg }\end{array}$ & Pastabos \\
\hline MS.406 & 1940 & 460 & 860 & $\begin{array}{c}1 \times 20 \mathrm{~mm} \\
2 \times 7,92 \mathrm{~mm}\end{array}$ & & Užsakyti \\
\hline $\begin{array}{l}\text { Gloster } \\
\text { Gladiator“ }\end{array}$ & 1938 & 410 & 860 & $4 \times 7,92 \mathrm{~mm}$ & & \\
\hline $\begin{array}{l}\text { PZL P.11g } \\
\text { „Kobuz“ }\end{array}$ & $1940 . \mathrm{IV}$ & & 840 & $2 \times 7,92 \mathrm{~mm}$ & & Užsakyti \\
\hline $\begin{array}{l}\text { PZL P.50A } \\
\text { „Jastrzeb“ }\end{array}$ & 1942 & 430 & 840 & $4 \times 7,92 \mathrm{~mm}$ & & 0 serija \\
\hline \begin{tabular}{l} 
I-16, 29 tipas \\
\hline $\begin{array}{l}\text { I-16, } \\
28 \text { tipas }\end{array}$
\end{tabular} & 1940 & 462 & 900 & $\begin{array}{c}1 \times 12,7 \mathrm{~mm} \\
2 \times 7,62 \mathrm{~mm}\end{array}$ & 200 & \\
\hline $\begin{array}{l}\text { I-16, } \\
20 \text { tipas }\end{array}$ & 1939 & 427 & 750 & $4 \times 7,62 \mathrm{~mm}$ & & \\
\hline $\begin{array}{l}\text { I-153 } \\
\text { „Caika“ }\end{array}$ & 1938 & 426 & 800 & $4 \times 7,62 \mathrm{~mm}$ & & \\
\hline I-15bis & 1937 & 379 & 750 & $4 \times 7,62 \mathrm{~mm}$ & & \\
\hline Bf-109E-3 & 1939 & 560 & 1175 & $\begin{array}{c}3 \times 20 \mathrm{~mm} \\
2 \times 7,92 \mathrm{~mm}\end{array}$ & & \\
\hline Bf-109E-1 & 1939 & 550 & 1050 & $\begin{array}{c}2 \times 20 \mathrm{~mm} \\
2 \times 7,92 \mathrm{~mm}\end{array}$ & & \\
\hline Bf-110C-1 & 1939 & 538 & $2 \times 1050$ & $\begin{array}{l}2 \times 20 \mathrm{~mm} \\
5 \times 7,92 \mathrm{~mm}\end{array}$ & & \\
\hline
\end{tabular}

96 Ten pat.

97 Ten pat, p. 72-86.

98 ЦАГИ им. проф. Н. Е. Жуковского, Самолетостроение в СССР 1917-1945 гг. Книга II, Москва, 1994. 
Akivaizdu, kad Vokietijos karo aviacijos naikintuvai savo didžiausiu greičiu ir ginkluote stipriai lenkẻ kitų šalių naikintuvus. Nepaisant didelės šių lèktuvų techninès ir Vokietijos karo aviacijos kiekybinès persvaros, iš visų kare su Lenkija naudotų lèktuvų Bf-109, kurių turèta 441, buvo visiškai sunaikinti 56 ir sugadinti $60^{99}$.

Doc. dr. V. Lesčius savo straipsnyje pateikia anksčiau man nežinomų dokumentų apie 1940 metais atliktus ANBO VIII vertinimus ir naujus reikalavimus Lietuvos karo aviacijai reikalingam žvalgybos ir atakos lèktuvui ${ }^{100}$. Vos pažvelgus i techninius duomenis akivaizdu, kad jie vos ne tiksliai atitinka ir kitų šalių prieš APK suformuluotus tuo metu labai populiaraus universalaus lėktuvo, galinčio kovoti su priešo naikintuvais, eskortuoti bombonešius, bombarduoti, taip pat ir pikiruojant, ir vykdyti oro žvalgybą, reikalavimus. Tačiau prieš APK kitų šalių karo aviacijoje atsirado tiktai du tokie lèktuvai, kurie, turèdami du variklius, galëjo pasiekti reikalaujamą greitį ir nešti nustatytą ginkluotę. Tai olandiškas „Fokker“ G.1, ir vokiškas Bf-110. G.1 buvo pagaminta tik keletas dešimčiu ir jo kovine karjera baigèsi po Olandijos okupacijos, o Bf-110 kariavo beveik visą laiką per APK, tiesa, vèliau jo užduotys buvo labai susiaurintos. Kiekvienam besidominčiam karo aviacijos istorija puikiai žinoma, kad universaliu lèktuvu Bf-110 netapo. Bf-110 negalèjo atlikti nei bombonešio, nei naikintuvo funkcijų. Dèl to „mūšio už Angliją“ metu Bf-110 ne tik kad nepajègė apginti lydimų bombonešių, bet ir susitikę su vienviečiais Didžiosios Britanijos naikintuvais būdavo priversti patys kaip bombonešiai stoti ì gynybinę „rato“ rikiuotę, t. y. esminę puolamają naikintuvo funkciją pakeisti i pasyviają gynybą. Tokią gynybos rikiuotę pirmąkart Bf-110 teko išbandyti jau Lenkijoje. Cia Vokietijos karinès oro pajègos (Luftwaffe) neteko 12 ir buvo apgadinti jos $27 \mathrm{Bf}-110$, patys sunaikino 12 senų PZL P.11 ${ }^{101}$, priklausančių Persekiotojų brigadai ${ }^{102}$. Bf-110 gerai pasirodė tik atakuodamas visiškai naikintuvų nedengiamus žemès taikinius. Tokių išskirtinių sąlygų - kad vieni galètų viešpatauti oro erdveje - Lietuvos karo aviacijos daliniai negalejo tikètis jokiomis aplinkybėmis. Todėl ir reikalavimai kurti tokias technines charakteristikas atitinkantį lèktuvą buvo nepamatuoti, nulemti objektyvios informacijos apie Vokietijos-Lenkijos karą stygiaus. Be to, dar viena itin svarbi priežastis - tinkamų variklių trūkumas - ribojo A. Gustaičio konstrukcines galimybes. Dèl to visiškai žlugo analogiškų lenkų lẻktuvų PZL P.38 „Wilk“

99 J. B. Cynk, Siły lotnicze Polski i Niemiec. Wrzesień 1939, s. 232.

${ }^{100}$ V. Lesčius, Lietuvos kariuomenès organizavimo, dislokavimo ir ginkluotès pokyčiai 1938-1940 m. // Karo archyvas, t. XXIV, p. 185-187.

${ }^{101}$ J. B.Cynk, Siły lotnicze Polski i Niemiec. Wrzesień 1939, s. 228.

${ }^{102}$ Brygada Pościgowa - Lenkijos karo aviacijos naikintuvų junginys, skirtas Varšuvos priešlèktuvinei gynybai. 
ir „Lampart“ bei naujų vienviečių naikintuvų programos. Be to, dviejų variklių lèktuvas yra brangesnis, didesnis, jam reikia didesnių aerodromų, daugiau degalų, patiriama kitų papildomų eksploatacijos išlaidų. Vadinasi, patikslinti reikalavimai $^{103}$ ANBO VIII klasès lèktuvui buvo per dideli ir nerealūs.

Labai nesiplèsdamas noriu pabrèžti žvalgybinès aviacijos svarbą Lietuvos kariuomenei. Žvalgomosios aviacijos statute nurodyta šių pajėgų paskirtis:

a) rinkti ir teikti žinias apie priešą ir savosios kariuomenès dalis;

b) bendradarbiauti kautynių lauke su kitomis ginklo rūšimis;

c) palaikyti ryši tarp vadovybès ir kariuomenès dalių ${ }^{104}$.

Štai E. Middeldorfožvalgybinès aviacijos vertinimas:,,Orožvalgybos duomenys yra pagrindas planuojant taktines aviacijos ir sausumos kariuomenès veiksmus. "105 1938-1940 m. nebuvo jokios kitos žvalgybos formos, galinčios atstoti ar pavaduoti oro žvalgybą. Nei agentūrinè, nei kariuomenès žemès žvalgyba negalëjo laiku suteikti tokios tikslios („čia ir dabar“) informacijos apie priešo kariuomenès, ypač greitu tempu žygiuojančių šarvuotujų/motorizuotujų pajègų, dydị, kryptį ir greitị, surasti atitrūkusias, apsuptas ar dèl kitų priežasčių ryšị praradusias savo dalis ir t. t. Oro žvalgybos fotografijų studijavimas net ir šaltojo karo metu neprarado savo reikšmès, tai svarbi žvalgybos sistemų dalis ir šiandien. Savaime suprantama, $\mathrm{kad} 500 \mathrm{~km} / \mathrm{h}$ pasiekiantis žvalgybos lèktuvas yra geresnis už skrendantį $430 \mathrm{~km} / \mathrm{h}$ greičiu. Tačiau 1938-1940 m. karo apimtoje Europoje tokių lèktuvų visai nebuvo arba nebuvo galimybių jų issigyti. Be to, gana sẻkmingai, netgi priešui visiškai užsitikrinus viešpatavimą ore, veikè ir senesnių tipų, prilyginamų ANBO IV ir ANBO 41 bei lètesnių už ANBO VIII, lèktuvai. Pvz., 1939-09-02 armijos „Modlin“ 53-iosios žvalgybos eskadros PZL-23 nuo 9.25 iki 11.00 val. žvalgè teritoriją nuo Choželès (Chorzele) ir Pšasnyšo (Przasnysz) iki Ščytnos (Szcytna) ir Velbarko (Wielbark) ir pastebejjo 3 vokiečiu kavalerijos kolonas. 11.00 val. Vokietijos teritorijoje prieš Nidzicos geležinkelio stotị bombomis atakavo prekinį traukinị, o pačioje stotyje iš kulkosvaidžių apšaude ant rampos susitelkusią kariuomenę. Grįždami miške dar nustatè vokiečių kavalerijos susitelkimo vietą ir kulkosvaidžiais ir „mažomis bombomis“ atakavo aptiktą 1 km ilgio pèstininkų koloną. Dar 2 tos pačios eskadros lèktuvai vykdè analogišką žvalgybą kitomis kryptimis ${ }^{106}$.

Be žinių rinkimo, ir kitos dvi statute numatytos žvalgomosios aviacijos funkcijos buvo labai svarbios. Dar įdomesnè Suomijos-Sovietų Sajungos

\footnotetext{
${ }^{103}$ V. Lesčius, Lietuvos kariuomenès organizavimo, dislokavimo ir ginkluotès pokyčiai 1938-1940 m. // Karo archyvas, t. XXIV, p. 186.

104 Žvalgomosios aviacijos statutas. Av-58, Kaunas, 1939, p. 5.

105 Э. Миддельдорф, Русская кампания: тактика и вооружение, Санкт-Петербург, 2000, c. 285.
}

106 T. Jurga, Obrona Polski 1939, s. 263. 
1939-1940 m. Žiemos karo patirtis. Tačiau šiuos ir kitus klausimus, Lietuvos karo aviacijos būklę ir kovinị pajègumą 1938-1940 m. tikiuosi išnagrinèti ir ivertinti atskirame, šiuo metu dar nebaigtame savo darbe.

\section{LIETUVOS KARIUOMENĖS GINKLAI}

Lietuvos kariuomenès ginklams skirta labai daug darbų. Dauguma jų išvardyti jau anksčiau. Bet informacijos vis dar trūksta. Tokia padėtis sudaro sąlygas internete plisti neteisingoms žinioms apie Lietuvos kariuomenès ginkluotę. Pvz., ivairiomis kalbomis internete paplito informacija apie neva daugybę $37 \mathrm{~mm}$ lenkiškų prieštankinių patrankų „W.Z. 36 Bofors“, taip pat turètų $40 \mathrm{~mm}$ patrankomis ginkluotų „Vickers“ tankų ir pan.

Trūksta ir informacijos apie lengvuosius šaulių ginklus, sunkiąsias pėstininkų priemones, artileriją, šarvuotają techniką. Juk Lietuvos kariuomenè išbandė ivvairius automatinius šautuvus, pistoletus kulkosvaidžius, buvo numatyta ịsigyti optinių taikiklių. Labai noretųsi žinoti tikslu Lietuvos kariuomenès turètų šaulių ginklų ir sunkiųų pėstininkų priemonių skaičiu bei tipus. Kol kas šie skaičiai ivvairiuose šaltiniuose skiriasi. Pvz., Lietuvos kariuomenės pistoletai „Browning FN“. V. Statkus nurodo, kad Lietuvos kariuomeneje buvo naudojami dviejų tipu pistoletai: vokiškas 9 mm 1908 m. „Parabellum“ ir 9 mm belgiškas „FN Browning GP 35“. Jis pažymi, kad karininkai ir liktiniai savo lěšomis įsigydavo mažesnių, lengvesnių ir patogesnių kitų gamintojų pistoletų, tačiau šių ginklų skaičiaus nenurodo ${ }^{107}$. Inž. plk. S. Birutis 1991 m. „Karyje“ išspausdintame straipsnyje (JAV) „Lietuvos kariuomenès ginklavimasis"108 nurodo, kad buvo įsigyta 3000 vnt. 9 mm pistoletu „Browning“. 1935-1941 m. slaptame Ginklavimo plane ${ }^{109}$, grafoje „Perkamas kiekis“, nurodyti 5000 vnt., o ,grafoje „Kiek turètų būti“ - 7000 vnt. pistoletų, kurių tipas nenurodytas. Iki šiol nèra aiškiai atsakyta į klausimą, kiek ir kada Lietuvos kariuomenè ịsigijo belgų firmos Herstalyje FN 9 mm pistoletų GP (HP). G. Surgailis pateikia tik bendrą turètų pistoletų skaičių - 12000 vnt. - ir nurodo jų tipus: „Browning“, „Parabellum“, „Walther PP“, PPK ir kt. ${ }^{110}$

Ilgą laiką apie pistoletus kulkosvaidžius ar jų bandymus Lietuvos kariuomenejje nebuvo galima rasti nieko, nors karo istorijos mėgèjų interneto forumuose diskusijos apie tai vyko nuolat. Tiktai doc. dr. V. Lesčiaus pateiktame Ginklavimo valdybos viršininko plk. dr. P. Lesauskio slaptame kariuomenei

${ }^{107}$ V. Statkus, Lietuvos ginkluotosios pajègos 1918-1940 metais, p. 524-525.

${ }^{108}$ V. Lesčius, Lietuvos -kariuomenès organizavimo, dislokavimo ir ginkluotès pokyčiai 1938-1940 m. // Karo archyvas, t. XXIV, p. 196-197.

${ }^{109}$ A. Liekis, Lietuvių karyba ir ginkluotè, p. 1038.

${ }^{110}$ G. Surgailis, Lietuvos kariuomene 1918-1998, p. 57. 
trūkstamo turto sąraše ${ }^{111}$ paminèta, kad reikètų 2500 vnt. automatinių pistoletų kulkosvaidžių. Kadangi Lietuvos kariuomenèje buvo bandomi (šaltinyje dèl korektūros klaidos nurodyta, kad buvo naudojami) pistoletas kulkosvaidis „Bergman“ ir karabinas kulkosvaidis „Neuhausen“112, galima daryti prielaida, kad vienas iš šiu automatinių ginklu ir būtu pasirinktas.

Manyčiau, kad Lietuvos kariuomenès istorijos mejgejjams, studentams ir visiems ja besidomintiems reikalingas žinyno formos leidinys, kuriame būtų pateikti pagrindiniai duomenys: glaustai papasakota apie tarpukario Lietuvos kariuomenę, jos organizavimą, ginkluotę ir kitus kariuomenès gyvenimo ir veiklos aspektus, ypač svarbiais 1938-1940 m., nurodyti reikšmingesni jos istorijos tyrimai. Kaip pavyzdi noréčiau pateikti jau daug kartų paminètą G. Surgailio darbą ${ }^{113}$, kurị, be abejo, būtina patikslinti ir papildyti. Drịstu teigti, kad toks leidinys, parengtas ne vieno, o grupès autorių, būtų išsamesnis ir įdomesnis.

\section{IŠVADOS}

1. Nepaisant to, kad atlikta nemažai tyrimų ir paskelbta reikšmingų darbų, tarpukario Lietuvos kariuomenès istorija lemtingais mūsų šaliai 1938-1940 m. vis dar nèra deramai nušviesta, liko daug neatsakytų ir diskutuotinų klausimų. Istorijos tyrimuose nepakankamai taikoma Lietuvos kariuomenès ir kitų to meto šalių kariuomenių lyginamoji analizè, beveik nenagrinëjama to meto karinių konfliktų ir Antrojo pasaulinio karo patirtis kariuomenès organizacijos, taktikos, ginkluotès ir kt. aspektais.

2. Dèl nepriklausomos Lietuvos Respublikos okupacijos atsirado takoskyra tarp Lietuvos ir išeivijos darbų ir šaltinių. I šių šaltinių ypatybes atliekant Lietuvos kariuomenès istorijos tyrimus būtina atsižvelgti. Kai kurie iš jų, pvz., Lietuvos kariuomenès statutai, retai naudojami.

3. Lietuvos kariuomenès istorijos tyrimuose turètų būti daugiau istorinių vertinimų, kurie, galbūt ir diskutuotini, ją praturtintų ir populiarintų.

4. Labai reikalingas žinyno formos, geriausiai grupès istoriku parengtas, leidinys apie tarpukario Lietuvos kariuomenę, jos istoriją, organizavimą, ginkluotę, kitus kariuomenès gyvenimo ir veiklos aspektus, kuriame būtų nurodyti ir svarbesni tyrimai.

\section{Iteikta $2010 \mathrm{~m}$. vasario $1 \mathrm{~d}$.}

\footnotetext{
${ }^{111}$ V. Lesčius, Lietuvos kariuomenès organizavimo, dislokavimo ir ginkluotès pokyčiai 1938-1940 m. // Karo archyvas, t. XXIV, p. 197-198.

112 E. Papečkys, Pèstininkai - Lietuvos kariuomenès placdarmas // Kardas, 2009, Nr. 4 (439), p. 51.

${ }^{113}$ G. Surgailis, Lietuvos kariuomenè 1918-1998.
} 